\title{
POSITION
}

\section{MENINGER I GALSKABEN}

I 1989 konstaterer man i Storbritannien et alarmerende stort antal køer der har stiv gang, virrende hoveder og en heftig omsigslikkende tunge. De fleste dør kort tid efter. Ved obduktionen finder veterinærer en hjerne fuld af huller, nærmest som en emmentalerost, eller en køkkensvamp. Sygdommen er set før og hedder bovin, for kvæg, spongio, for svamp, encephalitis, for hjernebetændelse, eller BSE. En analyse af hjernevævet viste store mængder af proteinstrukturen prion. Prionet, mener man, havde kvalt de grå hjerneceller indefra med fibrin.

Et prion er en udfoldning af et $\mathrm{i}$ organismen allerede eksisterende protein. Det betyder at kvæget ikke er i stand til at danne antistoffer mod prionet. Der er med andre ord intet immunforsvar der kan standse det. Ingen har endnu klarhed over hvad denne pludselige udfoldning af proteinet, Pr-P, til et prion skyldes. Men der verserer velbegrundede hypoteser om at der er tale om en kaskade-effekt, det vil sige: er ét prion først dannet, vil dette, givetvis via receptorer på cellernes overflade, forårsage udfoldningen af nye prioner. Der er heller ingen vished om hvorfor prionet tilsyneladende opkoncentreres i centralnervesystemet. Men det vanskeliggør diagnosticeringen af BSE. Det kræver en død ko.

Grunden til at man overhovedet ved så meget om prionet og dets virkemåde, skyldes først og fremmest lægers forskning i mennesker med Creutzfelt-Jacobs sygdom, CJS. Symptomerne på CJS ligner dem som kendes hos kvæg med BSE: lang inkubationstid, forstyrrelse af motorikken, gradvis udhulning af hjernen, og død efter et til to års sygdom.

Flertallet af de patterdyrarter der er undersøgt, er i stand til at udfolde prioner. Den genetiske kode for Pr-P, varierer dog fra art til art. Et interessant spørgsmål er imidlertid om et prion fra én pattedyrart kan igangsætte kaskader i et andet. Dyreforsøg har vist at det kan det. Dog skal der i flertallet af de tilfælde hvor det er muligt, meget store doser til, og i enkelte tilfælde kræves inokulation direkte på hjernen for at fremkalde de klassiske BSE-symptomer.

Prion tåler i modsætning til at andre proteiner, som for eksempel fribrin, en særdeles hårdhændet behandling. Det denaturerer således først efter længere tids kogning ved mere end 120 celciusgrader. Det var blandt andet denne observation der ledte de britiske veterinærmyndigheder på sporet af det kød- og benmel som mange britiske landmænd fodrer deres kvæg med. Blandt de døde dyr der anvendtes i fremstillingen af melet, var der en del får med sygdommen ,scrapie“, fårenes udgave af BSE. Temperaturen i trykko- 
gerne på kød- og benmelsfabrikkerne må have været for lav. En tese der blev bestyrket af det faktum at flertallet af BSE-tilfældene var konstateret i de proteinkonsumerende malkekvægsbesætninger.

Der er dog stadig intet der tyder på at mennesker kan smittes ved at spise oksekød fra kvæg med BSE. Det har heller ikke været muligt at spore nogle fælles epidemiologiske faktorer blandt de mennesker der har fået konstateret CJS: bopæl, karriere, spisevaner, o.l. Blandt de døde er der således én inkarneret vegetar. Endvidere kan det nævnes at frekvensen af CJS endnu ikke er større i det BSE-hærgede Storbritannien end andre steder i verden. $\mathrm{Og}$ som et kuriosum hører det med at man på Færøerne i lang tid har spist hjerner fra får med mulige forstadier til scrapie, uden at der her er nogen påviselig større frekvens af CJS. I dag (juni '96) tilslutter dyrlægerne ved de britiske veterinære myndigheder sig derfor formuleringen om ,,at det britiske oksekød er sikkert inden for den normale betydning af ordet“" (Blanchfield 1996).

I forlængelse af BSE-udbruddet blev der i Storbritannien talt en del om mad cow desease, eller kogalskab. Der blev produceret tv-film om den mystiske død hvis årsag man ikke kendte, eller rettere, nogen kendte den, men myndighederne ville ikke anerkende den. Det der i 1989 for alvor bragte de britiske sind i kog, var dog tanken om at britiske landmænd fodrer deres køer med foder fremstillet af andre køer. Ordet kannibalisme, blev nævnt flere gange.

\section{Britisk kødpolemik}

De britiske skoler var blandt de første til at indstille serveringen af oksekød til den traditionelle skolemiddag. Prisen på det subsidierede britiske oksekød faldt. Køer der udviste tegn som kunne tolkes som BSE, skulle slås ned, hovedet sendes til obduktion, og kroppen graves ned et forsvarligt sted på landmandens ejendom. Køers bevægelse fra opdrætter til slagter skulle registreres. De britiske landmænd klagede over endnu mere bureaukrati, over the antimeat lobby, over den hysteriske offentlighed: de var alle bange, mente landmændene, angrebet af the BSE-scare. Da undertegnede i efteråret 1994 besøgte kødproducerende landmænd på de nordatlantiske Orkneyøer, var BSE-stormen ved at stilne af. Opkøberne betalte igen det samme for kreaturer hvad enten de kom fra en BSE-fri besætning, eller ej. „Jaaa, that's right it looks like the one on television“, var en landmands konstatering efter dyrlægens dom. Landmænd med BSE-besætninger følte sig nu alligevel ,a bit stamped“. Værst var nok mistroen, den tabte tillid til det mange landmænd havde arbejdet med hele livet, og anså som first class products.

I marts i år påvistes der så i Storbritannien inden for et kort tidsrum en række tilfælde med en ny variant af CJS. Spørgsmålet var om der var en sammenhæng mellem den nye variant og udbruddet af kogalskab i 1989. På BBC vistes scener af pårørende til de nye tilfælde, et sort-hvidt foto af den ramte selv, en stivbenet ko i en boks med halm, og af og til en landmand i blå overalls. Indimellem var der glimt af dinglende slagtekroppe på blanke kødkroge, langs blodbestænkte fliser. Og en aften på BBC-News forklarede etologen Desmond Morris at briternes forskrækkelse over oksekødet nok var den samme som når dyr støder på et suspekt fødeemne, hvorefter Morris pludselig hiver øjenbrynene op i sin skaldede isse, trækker hænderne op under skuldrende og anlægger en nasal gnasken oven på sit ellers veltemperede oxfordengelsk. 
Den britiske premierminister John Major vaklede mellem at det muligvis var farligt at spise oksekød, og at risikoen var ubetydelig, og han blev af euroskeptikere beskyldt for the ban on British beef. Men hvad skulle der ske med de britiske køer: skulle de slås ned, og i givet fald, hvem skulle betale? Landbrugsminister Douglas Hogg lod sig fotografere offentligt med sin lille $\varsigma ø$, mens de sammen tager en bid af en britisk burger. Efter de første spontane nedslagtninger, forlyder det (juni '96) at alle dyr over 30 måneder skal aflives og sendes til destruktion.

Nogen vil mene at den britiske presse overdramatiserede, andre at den ligefrem forførte, men et faktum er det at befolkningen fik det stof der resonerede med deres frygt - der jo var begrundet videnskabeligt: ,sikker inden for ordets normale betydning“.

\section{I kødet}

Indbyggerne i Storbritannien går hele tiden rundt og er lidt utrygge: deres ejendele kan stjæles, deres samlever kan blive arbejdsløs, forleden blev en far til fem sprættet op af en transvestit, de kan rammes af hjerte-kar-sygdomme, kønssygdomme og kræft. Indtagelsen af fødevarer er, trods varedeklaration, en af de handlinger der er befængt med størst usikkerhed. Ubehaget ved at putte mad i munden er for mange britiske borgere, særligt kvinder, en daglig pestilens. Der er altid noget (IRA) men de ved ikke hvad, hvorefter nogle investerer i livsforsikringer og bedre sugeevne.

Affæren om kogalskaben har været endnu et emne at sætte ind i den spredte britiske uro. Alligevel kan det undre at det lige er oksekødet briterne har kastet deres skræk over. Hvorfor ikke fårekødet med scrapie eller komælken? Der er vel ingen grund til at tro at mælken i kartonen nede på hylden i den lokale Safeway, er fri for prioner.

Påstanden er at objektet for frygten er ikke en tilfældigt valgt fødevare. Det er fødevaren i pyramidens top, flagskibet på det britiske middagsbord: oksekødet, „the beef itself“. Det er ikke uden forankring at enkelte franskmænd kalder briterne L'hommes de bifstek, og hæfter sig ved deres gennemforberedte oksekød. Kogalskaben har været et stød lige i solarplexus på et af de stærkeste kulturelle systemer i Storbritannien, kødsystemet.

I det britiske kødsystem er kød, som den engelske socialantropolog Nick Fiddes foreslår, at betragte som et naturligt symbol (1991). Det vil sige, en let tilgængelig og derfor naturlig metafor til at udtrykke social erfaring. Køds aktuelle betydning er altid bestemt af systemets tilstand i det øjeblik det betragtes. Selve definitionen på fænomenet kød veksler således fra alt det som bevæger sig, til at ekskludere indvolde, til kun at være oversiden af den nederste del af oksens ryg, the sirloin. Ligesom man kan skelne mellem forskellige typer kød: „Rødt“, „,hvidt“, porch, poultry, wheel m.fl. Bacon indtager i den forbindelse en særlig interessant position, idet det befinder sig et sted mellem at være og ikke være kød. Én ting synes dog at ligge fast: man spiser kun ikke-menneskelige dyr, det vil sige dyr der enten ikke har nogen eksplicit emotionel tilknytning til mennesker eller er rovdyr. Måske er dette med til at forklare hvorfor den britiske offentlighed reagerede så voldsomt da det erfaredes at landmænd fodrer køer med andre drøvtyggere.

I kødsystemet er det muligt at skelne to samvirkende sider. Det der kan fastholdes som den klassiske og den moderne kødkultur. Eller det som en person med tendens til det første, kunne komme til at betegne som, henholdsvis „det rå“ og ,det krukkede“. I den klassiske kødkultur kan kødet antage karakter som: a real meal, den nødvendige protein 
ressource, Marvin Harris, overlegenhed, overflod, grill, farmand, boksning, rejsning, prestige, overdådighed, det vilde, det røde og frem for alt kontrol over Naturen. Som eksempel på den klassiske kødkultur bør fremhæves at man i bøger om børns opdragelse kan læse hvorledes man ved at nedsætte diætens kødmængde kan mindske drenges trang til at masturbere. Det som Norbert Elias om manerernes historie kalder civilisationsprocessen (1939), giver sig også til kende i den britiske omgang med kød: fra at blive sat midt på bordet $\mathrm{i}$ hel tilstand, udskåret med en stor kniv og indtaget med fingrene, bliver kød nu for det meste serveret i stykker, på individuelle tallerkener med selvstændigt bestik. Institutionen The Carvery, det populære og overflodsrige gaffel-selv-kød-bord, kan anskues som et sekulariseret snit fra denne proces.

Civilisationsprocessen og den raffinerede kødbehandling er dog ikke entydigt på den klassiske kødkulturs side. I den moderne kødkultur kan kød optræde som vegetarismens modpol, noget der er macho, blod, produktionsdyr, ondskab, gentry, pelsklædte kvinder, overgreb mod miljøet, disharmoni og misbrug af kontrollen over Naturen. Som eksempler kan nævnes det høje antal af briter der slet ikke spiser kød, ifølge Fiddes mere end fire procent i 1988. De vedholdende argumenter om at teorien om det animalske proteins nødvendighed er uden videnskabeligt belæg. Veganeres hyppige referencer til et særdeles velfungerende sexliv, når talen er om kød. (Potensen skulle efter sigende være renere, fri for kødets giftstoffer, men også moralsk, det har ikke været nødvendigt at slå ihjel for at få den op at stå.) Natlige bombeattentater mod kontorer på landbrugets forskningscentre, kontorer i hvilke der sidder mennesker der blandt andet forsker i etologisk tilpasset staldinventar. I slagterforretningerne er plancherne med de forskellige udskæringer erstattet af plakater med køer på friske enge med høstblomster i munden. Det røde der kan forbindes med aggressivitet og uhæmmet seksualitet, er domineret væk af det grønne der ånder ro og fred: green peace. Sidst, men ikke mindst, er det hakkede kød, the mince, blevet lagt ind i en delt bolle, dækket med grøn salat og har fået amerikanske rødder. Vi har at gøre med et af den moderne kødkulturs ypperligste udtryk, kødkamuflagen.

Med sagen om kogalskaben har miljøforkæmpere fået endnu et emne til listen der i forvejen indeholder Salmonella, E.-coli og østrogene hormoner. Den indflydelsesrige organisation Animal Welfare har fået endnu et bloddryppende kulturudtryk til at gå i spænd med de synligt rige kvinders pelse, denne gang de britiske landmænd i samfundets producerende periferi. Økologisterne har fået endnu grund til at „go organic“. Og ved den britiske kernefamilies spisebord har børnene fået endnu et hårdtslående argument for en kødfri hylde i køleskabet. „It's their own choice“, som en britisk moder docerede. Endnu flere døtre vil få anoreksi.

Men kogalskaben har også været en torn i øjet på de almindelige briter, som ellers havde vænnet sig til kødkamuflagen og det indpakkede kød i Safeway. Nu er det hele blevet afsløret, endda på tv, de dinglende kroppe og køernes stalde.

Man er dog endnu ikke begyndt at transmittere direkte fra de rum på slagteriet hvor man slår de levende dyr ned. De fleste briter må leve med troen på at også den del af processen kontrolleres af menneskehånd. For man vil, af grunde som er andre end frygten for fordærvet føde, for alt i verden, ikke spise selvdøde dyr. Med BSE-epidemien forsvinder også denne kontrol, nu begynder dyrene at dø af sig selv. 


\section{Ude af kontrol}

Der findes mange former for kontrol. Det britiske dagligdagssprog, og Nick Fiddes' afhandling i særdeleshed, er fyldt med udtryk der handler om kontrol: „to be in control“, „,control yourself“, „I do not particular like to be controlled“, og så, som nævnt, spøgelset i den britiske kødkultur: control over nature. Måske kan man ligefrem tale om kontroltrangen som en konstituerende omverdensrelation i briternes færden.

Hos den britiske socialantropolog Mary Douglas, som Fiddes teoretisk henter flittigt fra, er det kroppen der analyseres som et naturligt symbol. Andre af Douglas' tanker handler om at opretholde orden, og placere ting som ikke er med i denne (1966). En rå betragter vil hævde at teorien om naturlige symboler er endnu et udtryk for den britiske kontroltrang: Alt skal klassificeres, ordnes og udtrykkes før det kan forstås, især det der kommer ind og ud af kroppen. Man kan finde yderligere belæg for denne tolknings korrekthed ved at tage på en etnografisk rejse ind i de britiske husmødres badeværelser (der ikke må forveksles med ,wc“ som gør dem nervøse): lyserøde tæpper på brættet, hæklede sæbedyr i vinduet og en lyseblå duftkugle på kanten af kummen. Det er vel heller ikke tilfældigt at en anden kvindlig britisk social antropolog, Marilyn Strathern, betegner det britiske samfund som After Nature (1992).

Den britiske bornerthed gennemsyrer også Nick Fiddes' afhandling. Han undrer sig blandt andet over at den franske etnolog Claude Lévi-Strauss ikke har nogen speciel kategori for kød. Kød indgår hos Lévi-Strauss, bemærker Fiddes, blot på linie med andre fødevarer: from raw to cooked. Fiddes kan ikke hos Lévi-Strauss finde nogen på forhånd givet orden, ingen direkte kontrol, ingen overdreven kamuflage. Måske skimter vi her konturerne til et internationalt kødsystem i hvilket en franskmands bemærkning om det alt for tilberedte oksekød antager en anden betydning end blot at være en beskrivelse af briternes kødkultur.

Kogalskabens rystelser i kødsystemet trænger dog dybere ned end blot til det at putte noget udeklareret i munden. For hvad er galskab uden meningsløst tab af kontrol, over sig selv. Eller som det sattes i tale af en skotte: „If I am going to die, let it be quick, pleeease, a heartattack, for example“. „I shoot myself“, sagde en anden.

\section{Kødmod}

„But it’s cheaper“, bemærkede en britisk husfader, ,good cuts, sirloin, are $£ 5$ now, $£ 7$ before".

Trods BSE-panikken og et stigende antal vegetarer, ifølge et britisk dagblad nu mere end 8 procent, er der ingen grund til at tro at kødsystemet kollapser. Kødets værdi som samlende fænomen i det britiske samfund er stadig for stærk.

Det var også Nick Fiddes’ påstand da han i 1991 skrev sin ph.d.-afhandling om til en bog. Fiddes fremdrager kødkomforten. Bilen, mere præcist Limousinen, bliver Fiddes' private metafor. På de sidste sider i konklusionen citerer Fiddes et afsnit fra en roman af en amerikansk forfatter: Det er som at køre ned ad en vej i regnvejr, i sin Limo, mens man kigger på de mennesker der står ved stoppestederne, og venter på deres bus. Det er, ifølge Fiddes, omsonst at tro at salget af biler, store som små, ophører bare fordi det er blevet farligere at færdes i trafikken. 
Allerede $\mathrm{i}$ indledningen af afhandlingen understreger Fiddes vedholdende, at han, sin omgang med vegetarer til trods, selv er kødspiser. Hans modstand er dog umiddelbar, trods dens indirektehed. Og det er næppe tilfældets musik at hans konkluderende scenario ikke er en Rolls Royce fra Storbritannien, men en Limo fra USA. Sidstnævnte består i sin lukkethed og distance til andre, klassiske såvel som moderne former for kontrol.

Mere alvorligt er det med de britiske landmænd. Hvad skal de finde på - landmændene er vant til en skiftende verdensøkonomi, EU-regulativer, vejret og forbrugernes smag. For år tilbage råbtes der på ,,lean beeeef“'. De traditionelle amerikanske og skotske kødracer, hereford og angus, var for fede - i kødet. Den første havde for meget fedt langs kanten, og den sidste havde for meget inde i selve kødet. Man importerede tyre „syd fra“: blå-hvidt kvæg fra Belgien, simmenthaler fra Schweiz, charolais og limousine fra Frankrig. The continentals, som de hurtigt blev døbt af landmændene. De var slankere og mere muskulære - blå-hvidt kvæg har ligefrem dobbelte lår, to lag muskler oven på hinanden, fire quadriceps femoris. En stille hypotese kunne være den at man ved hjælp af splejsede gener kan fremavle en ny kvægrace der bevarer kødets fylde, men som ikke har arvet koden for proteinet Pr-P.

\section{Lidt om kød på stedet}

„The taste of Orkney“ er sloganet hvorunder man lancerer kød produceret på Orkneyøerne.

En producent fra Orkney, Brian, udtalte for et par måneder siden, ud over et langtrukkent „hmmm“, lige da han tog telefonen, at det nok slet ikke var så dumt at hans søn, Ian, for nylig har købt sine egne - får: ,,a good move, perhaps, yaaaa, ... buut, hmmm, if they kill all the beasts, now, hmm, there's gooing to be aaa shoortage' in a couplee a' yeears, hmmm, yaaaa“. Tilbage i 1992 havde Brians pensionerede far, Teddy, konstateret ud af bildøren: „Ahhh, Iannn', he's a bit of a dissapoinmen'. He is not so keen on cattl', he is more into machinery, he spend all his money at the Quayburray. Tooo much drinkin'“. Det var foran indkørslen til nabogården. Bagved pigtråden, i støvet fra forben, ulmede en lodden pande. Nogle store brølende sataner der forstyrrer nattesøvnen. Det mente Brian må være det konen på nabogården, Big Gladis, har følt, siden hun har beordret hans kvier væk fra indhegningen over for hendes mands tyr. Brian smiler. Vi går ad en smal asfaltvej. En byge spreder sig ud over næsset. „It's gooin' to rain“. Foran løber Brians medhjælp, Merwin, og viser kvierne vej. Brian fortæller om året før, da en landmand fra East Mainland gik ud på marken. Han havde sit pæne tøj på, og vandkæmmet hår. Han skulle give en ko en indsprøjtning, siger hans kone. Han kom ikke ud den aften, og heller ikke senere.

Et par dage tidligere havde der været et bullswop, Brian skulle bytte med Scottie. Tyren skulle op i en trailer. Men den kom ud, igen. Brian blev trukket langs siden af tyren til han sad fast i noget pigtråd. Tyren fortsatte gennem hegnet, der knækkede. Den trådte Brian i hovedet. Hans briller lå og var gået i stykker. Brian rejste sig fra græsset. Han sagde ikke så meget. Det plejer Brian ikke at gøre. Han var lidt skæv i hovedet, og han havde en flænge fra næsen og ned i munden. Teddy og Merwin grinede. Der var også lidt blod, det løb. 
„It's the bull that gives you ae growthy calvees, you see, it has to be pure bred. The coos have to beee good mothers, you see. Crosses tend to be better milkers". Voksdugen i køkkenet emmer af paperwork. Det er sidst på formiddagen. Margaret, Brians kone, er ved vasken, og åbner en Phillips slowcooker for sit dampende indhold. Men Brian vil alligevel forsøge at avle enkelte rene køer: „I got somm Limousine heeifers, they're threequaters, nooow, next generation will be seven out of eight, yaaaa, when they are fifteen parts out of sixteen, they couunt as pure ones. Maybe one day I'll have a pedigree bulll, how about thaat“, han smiler. „It really doesn't matter, when it all boils down, yaaaa, I mean, at the abattoir they are ranked according to fatcower and confirmation: $2 \mathrm{~A}, 3 \mathrm{~A}, 5 \mathrm{~B}$ ... Ask Ron, the Orkneymeatman“. Brian kigger ud af vinduet. Suppen rammer vasken, og lyden fylder rummet. „It takes yeearrs to build up a herd“, grunder Brian og forsvinder i voksdugen: „Got'to' fill in theem BSE papers“" - en ko er en ko til den dør.

Tao Kongsbak

\section{Litteratur}

Blanchfield, Ralph

1996 PROMED-AHEAD BSE IFTS. Position Statement, update, 23 May <www $>$.

Douglas, Mary

1966 Purity and Danger. London: ARK Paperbacks.

Elias, Norbert

1978 [1939] The civilising process. New York: Urizon.

Fiddes, Nick

1991 Meat: A natural symbol. London:Routledge.

Strathern, Marilyn

1992 After Nature: English kinship in the late twentieth century. Cambridge: Cambridge University Press. 
